УДК 378.014(73)

UDC 378.014(73)

DOI: $10.31475 /$ ped.dys.2020.28.05

ОЛЕНА КОЗЬМЕНКО,

кандидат педагогічних наук, доцент

(Украӥна, Севєродонецьк, Східноукраӥнський національний університет іл. В. Даля,

пр. Центральний, 59-A)

OLENA KOZMENKO,

Candidate of Pedagogical Sciences, Associate Professor (Ukraine, Sievierodonetsk, Volodymyr Dahl East Ukrainian National University,

Tsentralnyi prospect, 59a)

ORCID: 0000-0002-7063-2324

\title{
Реформа вищої освіти - шлях до успіху американських студентів
}

\author{
Higher Education Reform is the Way to American Students Success
}

Статтю присвячено проблемі рефбормування закладів вищої освіти США заради підвищення кількісних та якісних показників успіху студентів. Останні двадиять років питання ефбективності навчання студентів постає у зв'язку з недосконалістю освітнього процесу в трьох сфберах, які створюють бар'єри до успіху студентів. Заради подолання иих перешкод було запроваджено низку ребборм вищої освіти, серед яких "College Tech Prep" (1990) $i$ "Досягнення мрії: Громадський коледж» (2004) мали за мету надати суттеву допологу студенту в досягненні успіху. Дослідження показали, що хоча иі ініціативи $і$ мали короткостроковий ефбект, але не досягли загальної стабілізації показників успіху через вузьку спрялованість на окремі фбактори. Систела вищої освіти потребувала загальної ефбективної моделі рефборлування, що має орієнтацію на вимірювання успіху студентів, створюе базу доказів иього успіху $i$ пропонує цілеспрялований $i$ узгоджений набір колпонентів програми навчання. Прикладом такої ребборми є модель "Керовані шляхи", що була започаткована у 2013 році та зараз набувае все більшої популярності через свою ебективність. Центральним у иій рефборлі є створення для студента шляхів до завершення навчання, кар'єрного росту та подальшої освіти, що гарантує успіх студента.

Ключові слова: вища освіта США; рефорли; успіх студента; модель керованих шляхів; громадські коледжі.

The problem of reforms in US higher education in order to improve the student success is discussed in this article. Over the last twenty years, educators and policy makers have turned their attention to learning effectiveness, graduation rates and college completion. Higher education establishments, especially community colleges are not well organized to promote student success. They usually operate on a self-service or "cafeteria" model, allowing students to choose from an abundance of disconnected courses, programs, and support services. Such cafeteria organization creates problems in three areas: the structure of college-level programs, the intake process and student supports, and developmental education. Recognizing the importance of overcoming these problems, the process of improving higher education begins at the end of the twentieth century. In 1990 the College Tech Prep program, supported by Carl D. Perkins Vocational and Applied Technology Act, introduced the idea to provide purposeful support to students during their studies. In 2004, the Dream Achievement: Community College project proposed to overcome barriers to student success. An analysis of these reforms shows that they were narrowly targeted reforms, that have a limited effect on student success. They either treat too few people or are limited to one segment of the student experience. In contrast, the comprehensive model, which is fundamentally based on the integration of a set of coordinated reforms appeared in 2013. It was the guided pathways model, which presents courses in the context of highly structured, educationally coherent program maps that align with students' goals for careers and further education. The main purpose of this model is to support students throughout their college career by helping them choose a program, enter the program, complete the program, and make a successful transition to subsequent education or employment. The task of institutions is to monitor students' progress, use evidence on student progress and program effectiveness to improve graduation rates, as well as give frequent feedback and support as needed is.

Key words: US higher education; reforms; student success; the guided pathways; community colleges. 
Вступ / Introduction Протягом останніх десятиліть заклади вищої освіти США впроваджували різноманітні реформи та нововведення, намагаючись підвищити успіх студентів, зокрема «навчальні досягнення, рівень залучення до цілеспрямованої навчальної діяльності, ступінь задоволеності, набуття бажаних знань, умінь та навичок, розвинути наполегливість та досягнення освітньої мети» (Bridges B. et al., 2007). Але успіх е більш широким поняттям і не може бути визначений лише в межах кількісних показників зарахування, наполегливості та ступеня завершення. Ці показники, хоча є важливими, але повністю не враховують питання того, чи «студенти, які покладають надії щодо власного майбутнього на вищу освіту, отримують під час навчання те, що їм дійсно потрібно» (AAC\&U, 2007). Це питання й доволі широке визначення успіху студентів послужило основою для зусиль щодо вдосконалення процесів викладання та навчання в закладах вищої освіти США, створення служб підтримки студентів тощо. Останнім часом американські національні ініціативи почали зосереджуватися на необхідності впровадження загальнодержавної реформи, яка виходить за межі застосування окремих програм чи інновацій для того, щоби змінити базові структури та процеси ЗВО. Том Бейлі, національний експерт із питань вищої освіти, нещодавно зазначив, що «значне вдосконалення вимагає постійного процесу реформування та оцінки доказів вдосконалення, які мають бути закладені в культурі ЗВО й повинні включати цілеспрямований i узгоджений пакет компонентів, які впливають на всіх студентів протягом усього навчання в закладі» (Bailey T., 2017). У якості прикладу такої редорми він запропонував застосувати модель «Керовані шляхи». Цей рух передбачає створення узгоджених програм, надання необхідної допомоги студентам для навчання за цими програми, контроль прогресу студентів та організацію психолого-педагогічної підтримки студентів у разі потреби. Поступово реформа вищої освіти набирає обертів на теренах США, стає всебічною й системною, має позитивні результати щодо зміни основних структур і процесів закладів вищої освіти, зокрема громадських коледжів, заради успіху студентів. Ознайомлення 3 позитивним зарубіжним досвідом реформування вищої освіти $е$ корисним для української системи вищої освіти з метою імплементації сучасних тенденцій світової педагогіки.

Мета та завдання / Aim and Tasks. Метою статті є аналіз основних тенденщій реформування вищої освіти США заради досягнення успіху студентів. Відповідно до мети визначено основні завдання: здійснити ретроспективний огляд стану реформ вищої освіти в США з кінця XX початку XXI століття; охарактеризувати основні ідеї реформ, що стали передумовою моделі загальної реформи; розкрити зміст базових положень моделі Т. Бейлі «Керовані шляхи».

Методи / Methods. У процесі дослідження були використані такі методи:

- системно-структурний аналіз психолого-педагогічних праць із питань підвищення успіху студентів в США;

- порівняння, синтез та абстрагування для простеження розвитку трансформаційних змін вищої освіти в США;

- теоретичне узагальнення для формулювання і систематизації висновків, визначення подальших наукових розвідок у процесі редормування ЗВО.

Результати / Results. Лідери вищої освіти оцінюють успіх студентів, як найважливіший пункт із їхнього довгого списку пріоритетів. Починаючи з другої половини XX століття цим питанням зацікавилося багато американських дослідників, як-от: О. Астін, Б. К. Бріджіс, P. Брунінг, Е. Карpi, К. Каткенет, Дж. Кінзі, Дж. Ку, Дж. Хайек, К. Хорн, Дж. Шроу та ін. (Astin О., 1984; Horn K., 1993; Bridges B. et al., 2007), які представили різноманітні погляди на визначення, чинники й показники успіху. I все ж таки, незважаючи на готовність впроваджувати реформи $\mathrm{i}$ витрачати на них мільйони доларів, показники успіху закладів вищої освіти не стабілізуються. Питання трансформаційних змін ЗВО, переваги й недоліки освітніх реформ у США, досвід впровадження окремих ініціатив щодо покращення показників успіху широко обговорюються в наукових і академічних колах. Праці Т. О’Баньона, Е. Ганджи, Д. Дженкінса, Х. Лар, Дж. Фінка та ін. висвітлюють питання впровадження нового підходу до реформ (O’Banion T., 2019; Jenkins D. et al, 2018). На думку Т. Бейлі та його колег Ш. С. Джаггарс, Х. Лар, Дж. Фінка, Д. Дженкінс модель «Керовані шляхи» е тією ініціативою студентського успіху, яка спрямована на допомогу студентам обрати правильний шлях до успіху та залишатися на цьому шляху до завершення ЗВО (Bailey T., Jaggars S. S. \& Jenkins D., 2015). Ефективність цієї реформи полягає в тому, що вона ініціюе зміни щодо покращення процесу прийому, контролю навчання, підтримки студентів протягом навчання, спрощення структури навчальних планів та програм, залучення всіх учасників освітнього процесу до його вдосконалення (Jenkins D. et al., 2018). Такий дієвий перегляд роботи закладів вищої освіти зумовлено потребою у підвищенні рівня успішності студентів, їхньої профресійної самореалізації після закінчення ЗВО та особистісного розвитку. Оскільки ця реформа поступово набирає популярність у США, освітяни розробляють способи впровадження цієї ініціативи в роботу ЗВО (ААСС, 2012). Результати реформи доведено американськими освітянами емпіричним 


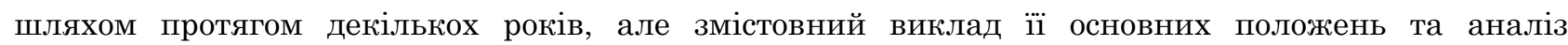
результатів на теренах нашої держави висвітлено недостатньо. Використання подібного досвіду редормування вищої освіти $е$ доволі актуальним для вдосконалення роботи українських університетів.

Обговорення / Discussion. Реформа вищої освіти, яка останнім часом усе більше привертає увагу педагогічної спільноти - це рух, мета якого - впорядкувати навчання студентів у ЗВО, надати їм структурований вибір програми, необхідну підтримку та чіткі щілі навчання, що в кінцевому рахунку, допомагає більшості студентів отримати кінцевий результат вищої освіти. Реформа визнає, що діюча модель роботи громадських коледжів не має чіткого плану для студентів щодо досягнення успіху, що призводить до нерозуміння студентами термінів навчання, обсягу необхідних знань та надмірної кількості кредитів. Але процес редормування вищої освіти відбувався протягом усіеї історії існування держави і приклади впровадження елементів сучасної трансформації почалися ще на початку XX століття. Перші спроби змінити ситуацію почалися у той час, коли окремі суспільні коледжі, на початку своєї роботи, стали залучати до навчання випускників місцевих шкіл. Коледжі укладали угоди із середніми школами щодо співпраці й це гарантувало студентам отримання чітких критеріїв за якими слід обирати курс навчання (сьогодні це $є$ елементом моделі «Керованих шляхів»). Протягом наступних десятиліть інформування та консультування студентів щодо розумного вибору курсів навчання та можливостей отримання освітніх послуг було ознакою успішних громадських коледжів у США. У 1980 -ті роки почався рух за оновлення і вдосконалення закладів освіти, який згодом перетворився на головну національну стратегію удосконалення академічних знань та технічних навичок студентів. I, вперше, ідея надання консультаційних послуг і супровід студентів під час навчання була впроваджена на законодавчому рівні в програму College Tech Prep у 1990 р. за підтримки Закону про профресійну та прикладну освіту Карла Д. Перкінса (Carl D. Perkins Vocational and Applied Technology Act). Ця програма стала «важливою інновацією в реформуванні освіти в США», оскільки надала учням можливість отримати вищу технічну освіту починаючи 3 дев'ятого класу школи (Тесh Рrep Education - U.S. Department of Education, 2020). Ставши доволі популярною, ця програма гарантувала отримання запланованої і послідовної освіти. Почавши навчання за спеціальністю в старших класах школи, після закінчення школи студент щонайменше ще два роки навчається в коледжі і здобуває вищу освіту або атестат. Програма Tеch Prep виконуе важливу стратегію переходу від школи до професійної діяльності й допомагає налагодити зв'язок між школою і 3 ВО. Програма містить сім обов'язкових елементів, що дозволяють об'єднати декілька закладів у єдиний консорціум, а саме: договір про співпрацю закладів середньої і вищої освіти, розроблену програму навчання 3 акцентом на вивчення математики, природничих наук, технологій $\mathrm{i}$ навичок спілкування, спеціально розроблений навчальний план, організація спільної спеціальної підготовки викладачів і шкільних вчителів до роботи за цією програмою, організація навчання консультантів для залучення студентів до навчання і їхнього супроводу до завершення програми та працевлаштування, обов'язковий рівний доступ усіх верств населення до програм Тесh Рrep; організація служби з надання консультаційної допомоги з підготовки до навчання, підбору роботи, особистого розвитку, кар'єрної реалізації, оцінки професійних можливостей. Програму Тесh Рrep, що реалізуеться в будь-якому коледжі, вважають едективною й надають першочергове фінансування, якщо вона: активно залучає до співпраці й консультацій представників бізнесу, промисловості, профспілок, інших ЗВО щодо можливостей вдосконалення навчання і професійного спрямування; пропонуе випускникам реальне працевлаштування, надає можливість для подальшого навчання за бакалаврськими програмами, застосовуе превентивні заходи щодо запобігання академічної заборгованості і відрахування з навчання, враховує потреби різних верств населення. Кожен штат отримуе федеральні кошти для реалізації програм Теch Prep. У 1995 році було майже 1029 об'єднань із реалізації програми Тесh Prep, але їхня кількість щорічно збільшуеться. У 1995 р. 737635 студентів у Сполучених Штатах були залучені до Tech Prep (Тесh Prep Education - U.S. Department of Education, 2020). На початку XXI століття з'являеться нова ініціатива американських освітян, яка ілюструе основні характеристики напряму реформ того часу, але містила в собі ще один елемент моделі «Керованих шляхів». Заради втілення чіткої мети покращення результатів студентів у 2004 рощі Фонд Lumina та його партнери ініціювали проект «Досягнення мріі: Громадський коледж» (The Achieving the Dream: Community Colleges Count (ATD) та фрінансували двадцять сім коледжів для впровадження низки інновацій. Згодом до цієї ініціативи долучилося ще кілька сотень коледжів (Вailey Т., 2017). Основою редорми стала ідея використовувати дані власних лонгітюдних досліджень коледжами заради виявлення перешкод на шляху до успіху студентів. Такий аналіз та застосування редорми на основі доказів дозволяють виправити ці бар'ери та збільшити кількість студентів-випускників. «Досягнення мрії: Громадський коледж» пропонує сім напрямків для створення в коледжах культури, орієнтованої на 
сприяння успіху студентів, реформуванню освіти. Ці напрямки стосуються таких сфер, як: лідерство, коли керівники ЗВО демонструють бажання співпрацювати щодо створення спільної концепції успіху студентів; використання сучасних технологій для збору, аналізу та використання даних щодо успіху студентів; організація рівних можливостей досягнення успіху для всіх студентів, незалежно від їхнього соціально-економічного статусу, расового та етнічного походження, особливих потреб; зміни у сфері викладання й навчання передбачають професійний розвиток професорсько-викладацького складу, підвищення рівня педагогічної майстерності й розуміння власної відповідальності за освітній процес, надання необхідної активної підтримки студентам в процесі навчання та поза його межами, оновлення системи підтримуючої освіти; ефективне спілкування і створення активних стратегічних партнерських відносин зі стейкхолдерами освіти для роботи в програмі успіху студентів та покращенні результатів навчання; розробка стратегій і планування е необхідними для узгодженої роботи закладу заради досягнення мети навчання, перетворення бажаних результатів на чітко визначені цілі та завдання й організація виконання дій для їх досягнення; політика закладу має значний вплив на успіх студентів і подолання бар'єрів його досягнення (Achieving the Dream, 2020). Досягнення змін у ЗВО відбуваеться за підтримки тренерів і дослідників, обміну досвідом під час семінарів і конференцій. Отже, ця ініціатива $є$ прикладом реалізації реформування вищої освіти в США, але на думку дослідників, така реформа «спрямована лише на один сегмент студентського досвіду (як правило, на початок навчання)», тому мала досить незначну ефективність щодо досягнення успіху студентів (Bailey T., 2017). Аналіз цілеспрямованих реформ у ЗВО показуе, що, навіть, тоді, коли вони позитивно впливають на короткострокові результати - такі, як рейтинг зарахування та успішність на першому році навчання - згодом отримані студентами переваги, як правило, зникають протягом наступних семестрів (Visher M. G. et al., 2012). Заради покращення успіху студентів, підвищення рейтингу завершення навчання, ЗВО мають спочатку зосередитися на розробщі відповідних критеріїв успішності студентів, зібрати докази відповідності цих критеріїв і проаналізувати ефективність, i, нарешті, реформа не може бути обмежена невеликою групою студентів або одним сегментом студентського досвіду. Отже, більшість освітніх організацій США, які прагнули досягти успіху студентів різними шляхами, сходилися на ключовій ідеї - студентам необхідна дорожня карта навчання, яка допоможе досягти кінцевого результату навчання й гарантуе необхідну підтримку на шляху до успіху. Томасом Бейлі та його колегами з науково-дослідного центру громадських коледжів (Community College Research Center) було запропоновано назву цієї дорожньої карти «керовані шляхи» («guided pathways»). Підсумовуючи результати багатьох досліджень Т. Бейлі вважае, що ефективна повномасштабна реформа вимагае трьох елементів: оріентації на вимірюваний успіх студентів; створення бази необхідних доказів; і цілеспрямований і узгоджений комплект компонентів програми (Bailey T., 2017). На думку освітян, «потрібно залучати фахівців із питань освіти, викладачів та консультаційні студентські служби для створення більш чітко структурованих, узгоджених навчальних програм, які ведуть до кінцевого результату студентів та вимагають переоріентації служб допомоги та підтримки студентів у такий спосіб, щоби за допомогою цих керованих шляхів полегшити навчання та покращити успішність студентів» (O’Banion T., 2019). Отже, заради покращення доступності навчання та успіху студентів необхідна фундаментальна реформа, що змінить структуру навчання. Модель «керованих шляхів» є одним із прикладів ефективної реформи, яка поєднуе три елементи, які зазначив Т. Бейлі (Bailey Т., Jaggars S. S. \& Jenkins D., 2015). Вона містить взаемозв'язаний пакет компонентів, побудований на розробці спрощених, добре організованих та зрозумілих програм навчання в коледжу. У цій моделі все логічно послідовно, оскільки спочатку організовуеться процес прийому до коледжів, що передбачае допомогу студентам у виборі програми навчання, потім увага спрямовуеться на діагностику й усунення академічних недоліків, які заважають студентам досягти успіху за обраною програмою. Наступним кроком е підтримка студентів протягом усього навчання в коледжі з метою завершення програми та успішного переходу до подальшої освіти або працевлаштування. Така реформа акцентуе увагу освітян на необхідності контролю прогресу студентів, наданні підтримки, оцінюванні, налагодженні зворотнього зв'язку й обговоренні успіхів студентів. Переваги моделі керованих шляхів порівнюючи з традиційним навчання полягають у створенні інноваційних змін чотирьох суттевих сфер закладів вищої освіти: структурі академічної програми, процесі прийому на навчання, навчально-виховному процесі, організації моніторингу прогресу студента та його підтримці (Jenkins D. et al., 2018). Згідно з реформою академічні програми повинні складатися 3 урахуванням подальшої освіти та кар'єрної реалізації студентів, тобто надавати студенту можливість набути необхідних для його професії знань, умінь і навичок; найважливіші курси та інші ключові результати мають бути чітко визначені на програмних мапах, а результати навчання студентів визначаються за окремими програмами. Інноващіям підлягає принцип складання розкладу занять для студентів згідно з їхніми планами, але з огляду на індивідуальні потреби 
студентів. Відповідно до нової реформи, навіть навчальні програми середньої школи мають бути спрямовані на підготовку учнів до навчання у ЗВО, тобто враховуючи формування необхідних навичок. 3 появою чіткої карти програм для студентів, стае нагальним створення академічного плану. Карта та академічний план допомагають студенту під час вступу до коледжу дослідити спеціальності та обрати конкретні програми у визначені періоди навчання. Формування фундаментальних навичок для майбутньої професійної кар'ери е вкрай важливим і передбачає інтеграцію необхідних знань і умінь у найважливіші курси програми. Важливим аспектом реформи є оцінювання, мета якого - дослідити прогрес і визначити ті сфери навчання, де студенту необхідна допомога й підтримка. У межах освітнього процесу зміни відбуваються в ставленні викладачів до визначення й оцінювання результатів навчання студентів, розвитку співпраці 3 науковцями й колегами щодо поліпшення якості викладання, впровадження інноваційних методів у навчальний процес, надання мотиваційної підтримки й допомоги студентам під час навчання. Процес моніторингу відіграе ключову роль у новій моделі керованих шляхів, оскільки надає можливість отримати зворотній зв'язок від студентів і вчасно відкоригувати навчальний процес. Також регулярне відстеження результатів студента дозволяе йому бачити власний прогрес та планувати подальші кроки до завершення програми. Рання діагностика проблем студентів під час навчання сприяе вчасному втручанню у вигляді відповідної допомоги, що має попередити ризик відрахування. Успішна співпраця консультантів-радників і викладачів е ефективним засобом моніторингу результатів студентів (Bailey T., Jaggars S. S. \& Jenkins D., 2015).

Що стосуеться тих основних можливостей, які надає реформа «Керовані шляхи», то «дослідження та досвід у цій галузі свідчать про те, що ці можливості е важливими для мотивації та підтримки закладів вищої освіти на шляху реформування» (What is the "Pathways Model?», 2018). Основні можливості, які отримують заклади вищої освіти завдяки реформі це позитивні зміни у власних структурах і процесах. По-перше, це зміни у сфері управління закладом, тобто впровадження такого керівництва, що демонструе навички ефективного управління та підтримання масштабних трансформаційних змін. По-друге, широке та справжне залучення викладачів та співробітників ЗВО, особливо консультантів-радників, до розробки, впровадження, оцінки та постійного вдосконалення програм для студентів. По-трете, усвідомлення необхідності змінити процес моніторингу студентів, а саме мати бажання та знайти можливість фіксувати прогрес студентів, використовувати ці дані, як докази для розробки навчальних та кар'ерних шляхів, моніторингу успішності студентів та впровадження в подальшому необхідних удосконалень. Для цього потрібна розробка відповідних технологічних інструментів та інфраструктури для підтримки успішності студентів через керовані шляхи, впровадження стратегічно орієнтованого професійного розвитку професорсько-викладацького складу для розробки стратегій підтримки. Потребують змін і умови політики, як на державному, так і та інституційному рівнях, що забезпечують стимули, структуру та підтримку проектування та впровадження шляхів. Розробка плану тривалого й масштабного дослідження ефрективності керованих шляхів у ЗВО сприяе створенню практичних рекомендацій, що е інструментами для підтримки масштабної ефективної реалізації реформи. Американська асоціація коледжів та університетів (American Association of Colleges and Universities (AAC\&U) визначила цю реформу, як вкрай важливу для американської вищої освіти. У звіті 2007 року було зазначено, що «на всіх рівнях - національному, регіональному та місцевому - головне завдання ЗВО - розробити шляхи допомоги студентам у досягненні успіху, а саме рекомендації, нові навчальні плани та завдання, що пов'язують насичений зміст з ефективним оволодіння студентами необхідними знаннями, навичками та вміннями» (AAC\&U, 2007). У дослідженні Т. О’Баньона було зазначено, що на початку другого десятиліття «після багаторічних досліджень щодо підвищення успішності студентів, вища освіта тепер чітко формулюе те, що потрібно для підтримки успіху студентів, і у який спосіб його досягти. ... студентам потрібен «компас» або чітко окреслений шлях для підтримки їхнього успіху, а самому ЗВО потрібен продуманий і задокументований шлях для підтримки студентів» (O’Banion Т., 2019). Американська дослідниця Кей МакКліні також сприяла формуванню моделі керованого шляху і спільно зі своїми колегами з Американської Асоціації громадських коледжів узяла участь у реалізації національного проєкту для тестування моделі в 30 громадських коледжах на початку другого десятиліття XXI століття. Цілі проєкту відображають рекомендації, викладені в доповіді Комісії XXI століття про майбутне суспільних коледжів «Відновлення американської мрії» (ААCC, 2012). Зокрема, у звіті комісії наголошувалося на необхідності ЗВО принципово переробити структуру навчання за допомогою конкретної стратегії, яка стала основою для проекту «Керовані шляхи» - побудувати узгоджені, структуровані шляхи до отримання кінцевої мети завершення навчання (АACC, 2012). Отже, вздовж шести років підхід «Керовані шляхи» став національним рухом реформ в американських ЗВО, зокрема в суспільних коледжах. Основні національні освітні організації, такі, як Американська асоціація громадських 
коледжів (ААCC), Агенції вищої освіти та Центри успішності студентів допомагають коледжам по всій країні впроваджувати реформи. За даними на весну 2018 року до проекту долучилось близька 250 коледжів з 14 штатів у рамках національних, державних чи регіональних програм; багато інших коледжів роблять це самостійно (Jenkins D. et al., 2018). 3 огляду на високу результативність ціеї реформи, численні практичні і теоретичні дослідження ефективності цього руху, статистичні показники успіху студентів тих ЗВО, які впроваджують цю модель протягом кількох років, можна припустити, що таке оновлення освітнього процесу у вищій школі буде розповсюджено і надалі.

Висновки / Conclusions. Отже, реформування вищої освіти в США е вкрай важливим, оскільки дозволяе здійснити трансформаційні зміни в інтересах студентів. Але впровадження вузько цілеспрямованих реформ, які стосуються малої кількості студентів або сфокусовані на змінах певної категорії студентського контингенту мають обмежений вплив на успіх студентів. Проте, модель загального реформування, що була запропонована на початку другого десятиліття XXI ст., має принципово інше підгрунтя й будуеться на інтеграції декількох скоординованих реформ, що дозволяе підвищити показники успішності студентів. Основна мета ціеї моделі підтримка студентів протягом навчання у ЗВО, завдяки послідовним діям із боку персоналу закладу. «Керовані шляхи» мае чотири ключові пункти, які відрізняють їі від інших: по-перше, вона сприяе уточненню шляхів до досягнення цілей, по-друге, допомагає студентам обрати шлях і його дотримуватися, по-трете, надае постійну підтримку студентам залишатися на шляху досягнення результату i, по-четверте, дозволяе контролювати навчання студентів. Допомагаючи студентам обрати програму, вступити на навчання за цією програмою, вчасно завершити навчання та перейти до подальшої освіти або працевлаштування, редорма «Керовані шляхи» підкреслює необхідність цілеспрямованої взаемодії зі студентами та контролю їхнього успіху. За підтримки багатьох освітніх організацій, національних лідерів та фінансової підтримки фондів, концепція керованих шляхів має всі шанси стати одніею з найбільш трансформуючих ідей сучасної вищої освіти.

Список використаних джерел і літератури:

Achieving the Dream. (2020). Retrieved from https://www.achievingthedream.org/our-network/our-approach) [in English].

American Association of Community Colleges. (2012, April). Reclaiming the American Dream: A report from the 21st-Century Commission on the Future of Community Colleges. Washington: Author. Retrieved from http://www.aacc.nche.edu/21stCenturyReport [in English].

Association of American Colleges and Universities. (2007). College Learning for the New Global Century: A Report from the National Leadership Council for Liberal Education and America's Promise. Washington: Association of American Colleges and Universities [in English].

Astin, A. W. (1984). Student Involvement: A Developmental Theory for Higher Education. Journal of College Student Personnel, 25 (4), 297-308 [in English].

Bailey, T., Jaggars, S. S., \& Jenkins, D. (2015). What We Know about Guided Pathways. New York: Columbia University, Teachers College, Community College Research Center [in English].

Bailey, T. (2017, May/June). Community Colleges and Student Success: Models for Comprehensive Reform. EDUCAUSE Review, 52 (3), 33-42 [in English].

Bridges, B. K., Kuh, G. D., Kinzie, J., \& Hayek, J. C. (2007). Piecing Together the Student Success Puzzle: Research Propositions and Recommendations. San Francisco: Jossey-Bass [in English].

Horn, C., Bruning, R., Schraw, G., Curry, E., \& Katkanant, C. (1993). Paths to Success in the College Classroom. Contemporary Educational Psychology, 18, 464-478 [in English].

Jenkins, D., Lahr, H., Fink, J., \& Ganga, E. (2018). What We are Learning about Guided Pathways. Part 3: Timeline and Tips for Implementing Pathways Reforms. New York: Columbia University, Teachers College, Community College Research Center [in English].

O'Banion, T. (2019). 13 Ideas That Are Transforming the Community College World. Rowman \& Littlefield. [in English].

Tech Prep Education - U.S. Department of Education. (2020). Retrieved from https://www2.ed.gov/about/offices/list/ovae/pi/cte/techprep.html [in English].

Visher, M. G. et al. (2012, July). The Effects of Learning Communities for Students in Developmental Education: A Synthesis of Findings from Six Community Colleges. New York: National Center for Postsecondary Research. Retrieved from https://www.mdrc.org/publication/effects-learning-communities-students-developmentaleducation) [in English].

What is the "Pathways Model?». (2018). Retrieved from https://www.aacc.nche.edu/wpcontent/uploads/2018/01/12PathwaysModelDescriptionFinal1616.pdf [in English].

References:

Achieving the Dream. (2020). Retrieved from https://www.achievingthedream.org/our-network/our-approach) [in English].

American Association of Community Colleges. (2012, April). Reclaiming the American Dream: A report from 
the 21st-Century Commission on the Future of Community Colleges. Washington: Author. Retrieved from http://www.aacc.nche.edu/21stCenturyReport [in English].

Association of American Colleges and Universities. (2007). College Learning for the New Global Century: A Report from the National Leadership Council for Liberal Education and America's Promise. Washington: Association of American Colleges and Universities [in English].

Astin, A. W. (1984). Student Involvement: A Developmental Theory for Higher Education. Journal of College Student Personnel, 25 (4), 297-308 [in English].

Bailey, T., Jaggars, S. S., \& Jenkins, D. (2015). What We Know about Guided Pathways. New York: Columbia University, Teachers College, Community College Research Center [in English].

Bailey, T. (2017, May/June). Community Colleges and Student Success: Models for Comprehensive Reform. EDUCAUSE Review, 52 (3), 33-42 [in English].

Bridges, B. K., Kuh, G. D., Kinzie, J., \& Hayek, J. C. (2007). Piecing Together the Student Success Puzzle: Research Propositions and Recommendations. San Francisco: Jossey-Bass [in English].

Horn, C., Bruning, R., Schraw, G., Curry, E., \& Katkanant, C. (1993). Paths to Success in the College Classroom. Contemporary Educational Psychology, 18, 464-478 [in English].

Jenkins, D., Lahr, H., Fink, J., \& Ganga, E. (2018). What We are Learning about Guided Pathways. Part 3: Timeline and Tips for Implementing Pathways Reforms. New York: Columbia University, Teachers College, Community College Research Center [in English].

O'Banion, T. (2019). 13 Ideas That Are Transforming the Community College World. Rowman \& Littlefield. [in English].

Tech Prep Education - U.S.Department of Education. (2020). Retrieved from https://www2.ed.gov/about/offices/list/ovae/pi/cte/techprep.html [in English].

Visher, M. G. et al. (2012, July). The Effects of Learning Communities for Students in Developmental Education: A Synthesis of Findings from Six Community Colleges. New York: National Center for Postsecondary Research. Retrieved from https://www.mdrc.org/publication/effects-learning-communities-students-developmentaleducation) [in English].

What is the "Pathways Model?". (2018). Retrieved from https://www.aacc.nche.edu/wpcontent/uploads/2018/01/12PathwaysModelDescriptionFinal1616.pdf [in English].

Дата надходження статті: «15» квітня 2020 р.

Стаття прийнята до друку: «02» червня 2020 р.

Козьменко Олена - заступник директора 3 навчально-методичної та виховної роботи Навчальнонаукового інституту міжнародних відносин Східноукраїнського національного університету ім. В. Даля, кандидат педагогічних наук, доцент

Kozmenko Olena - Deputy Director of Educational, Methodical and Upbringing Work of the Educational and Scientific Institute of International Relations of Volodymyr Dahl East Ukrainian National University, Candidate of Pedagogical Sciences, AssociateProfessor

\section{Цитуйте иљю статтю як:}

Козьменко, О. (2020). Реформа вищої освіти - шлях до успіху американських студентів. Педагогічний дискурс, 28, 39-45. doi: 10.31475/ped.dys.2020.28.05.
Cite this article as:

Kozmenko, O. (2020). Higher Education Reform is the Way to American Students Success. Pedagogical Discourse, 28, 39-45. doi: 10.31475/ped.dys.2020.28.05. 